\title{
Nationalt tilhørsforhold og holdninger til EF
}

\author{
Af Jørgen Elklit
}

\section{Indledning}

Formålet med denne afhandling ${ }^{1}$ er at undersøge sammenhængen mellem nationalt tilhørsforhold $\mathrm{i}$ Nordslesvig og indstilling til EF. Spørgsmålet er, i hvilken grad holdningen til Danmarks indtræden i De europxiske Frllesskaber - og til udvidet europxisk samarbejde i det hele taget - er afhængig af, om man er dansksindet eller tysksindet, og af hvor stærkt man foler sig knyttet til sin nationale gruppe. Undersøgelsens materiale er indsamlet i forbindelse med 2 interviewundersøgelser, som forfatteren gennemfører sammen med kolleger ved Aarhus Universitet. ${ }^{2}$

I forbindelse med den ene af disse undersøgelser mener vi at have fået et forholdsvis pålideligt billede af de nationale tilhørsforhold $\mathrm{i}$ Nordslesvig. Og det er et godt udgangspunkt for at se på, om for eksempel de anti-tyske overtoner, der sporedes $i$ visse dele af EFdebatten, havde mødt særlig genklang $\mathrm{i}$ dele af den nordslesvigske vælgerbefolkning. Dette var på forhånd måske ikke særlig sandsynligt; men også konstateringen af, at det ikke havde været tilfældet, ville kunne bidrage væsentligt til at karakterisere det aktuelle forhold mellem flertal og mindretal.

Inden disse $o g$ andre centrale problemstillinger tages op ( $i$ afsnit 4), vil det dog være på sin plads at give en kort redegørelse for de 2 interviewundersøgelser. Det vil ske $i$ den resterende del af dette indledende afsnit. Dernæst vil afsnit 2 bestå $i$ en mere almindelig redegørelse for udfaldet af folkeafstemningen $i$ hele det sønderjyske amt, mens emnet $i$ afsnit 3 vil være de holdninger til EF, vi konstaterede i 1971 ved den første af de 2 undersøgelser. Herved vil der være skabt en baggrund for sammenstillingerne i afsnit 4 af forskel- 
lighederne mellem de 2 nationale grupper med hensyn til holdninger til EF og til europæisk integration i øvrigt.

Den første af de 2 interviewundersøgelser har især koncentreret sig om en række forhold i forbindelse med det tyske mindretal. ${ }^{3} \mathrm{Et}$ af dens hovedformål ${ }^{4}$ er at undersøge forskellige definitionsmåder som grundlag for at bestemme størrelsen af det tyske mindretal i Nordslesvig. I et foreløbigt arbejde inden for denne problemstilling har vi hævdet det synspunkt, at et individ har et bestemt nationalt tilhørsforhold i den udstrækning, det deler de fælles holdninger, som er særegne for den pågældende nationale befolkningsgruppes kultur. ${ }^{5} \mathrm{Vi}$ har dér nærmere gjort rede for, hvorledes vi har arbejdet med 2 forskellige udtryk for det nationale tilhørsforhold, som i deres resultater viser sig at stemme udmærket overens. Det kan kun styrke tilliden til, at de også er udtryk for det, vi tror, nemlig det nationale tilhorsforhold.

Som det første af de to nationalitetsudtryk har vi de adspurgtes eget udsagn om, hvilken national gruppe de tilhører. Det har vi kaldt den subjektive nationale identifikation. For det andet har vi i forskellige former for adfærd et mere direkte iagttageligt udtryk for det nationale tilhørsforhold, idet vi mener, at dette blandt sine konsekvenser netop har en disposition for bestemte former for adfxerd. I mangel af et bedre udtryk har vi kaldt det på grundlag heraf konstruerede mål for den adfardsmassige nationale identifikation. ${ }^{6}$

I denne sammenhæng er det af særlig interesse, at undersøgelsen blandt en lang række forskelligartede problemer også interesserer sig for den nordslesvigske befolknings holdning til EF.

Undersøgelsen gennemførtes $i$ forbindelse med folketingsvalget $i$ september 1971, idet de samme 931 sønderjyske vælgere blev interviewet før og efter valget. Der var altså tale om en såkaldt panelundersegelse. De 931 personer udgjorde tilsammen 2 forskellige repræsentative stikprøver. Fordelen ved at arbejde med sådanne stikprøver er, at det inden for visse statistiske usikkerhedsgrænser er muligt at udtale sig om forholdene $i$ hele den befolkningsgruppe, som stikprøven er udvalgt af. For at sikre, at et rimeligt stort antal mindretalsmedlemmer kom med i undersøgelsen, blev den ene stikprøve (stikprøve 1) udvalgt $\mathrm{i}$ Tønder Købstad og i de 7 kommuner - fra før Kommunalreformen - hvor Slesvigsk Parti ved folketings- 


\section{Giro 47:}
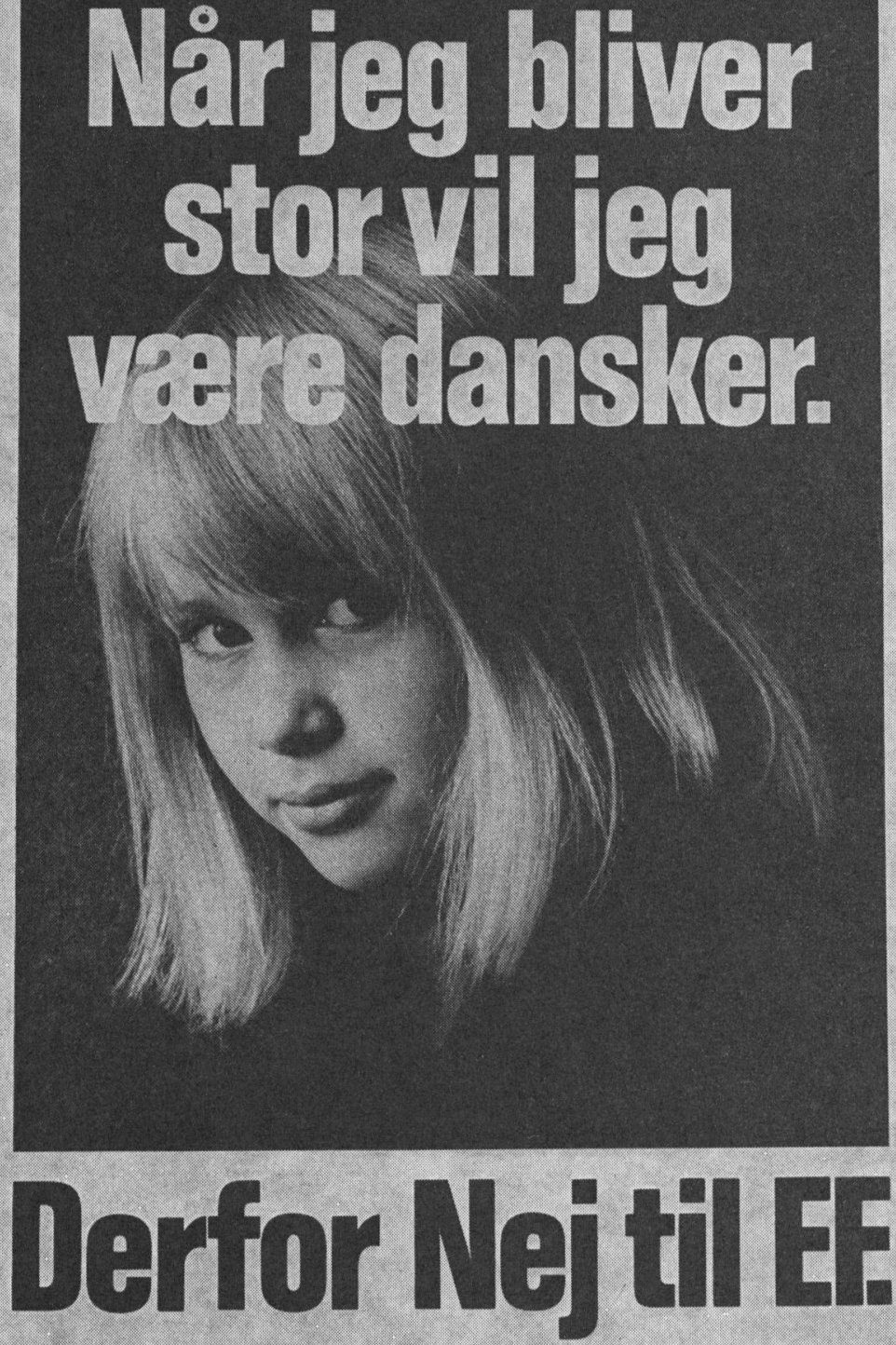

Folleterwedines imad EF

Barnets afbongighed af de voksnes afgørelser er et ofte benyttet propagandatema. Det indgik ogsa $i$ kampagnen $i$ forbindelse med afstemningen $i 1920$. 
valget i 1968 havde haft tilslutning fra mere end 20 pct. af samtlige valgberettigede. ${ }^{7} 637$ af de interviewede hører til denne stikprøve. De resterende 294 (stikprøve 2) udvalgtes således, at de skulle være reprasentative for hele amtet.

Den anden af de 2 interviewundersøgelser, hvorfra materiale er hentet, er den såkaldte "EF-undersøgelse «. Denne interviewundersøgelse er en del af et større projekt, hvis fælles formål er at forsøge at forklare en række forhold omkring folkeafstemningen den 2. oktober 1972.8 I interviewskemaet indgik blandt andet en række spørgsmål om holdninger til EF, der også var blevet stillet i 3 tidligere undersøgelser, herunder den ovennæunte i 1971 i Nordslesvig. En sammenligning af udviklingen over tid $i$ disse holdninger blev herved muliggjort. Også EF-undersøgelsen gennemførtes som en panel-undersøgelse. Et særligt forhold ved den er, at interviewingen efter folkeafstemningen også omfattede en rakke personer, der ikke havde været med i 1. interviewrunde i forsommeren 1972, men som derimod havde været med $i$ en af de 3 tidligere undersøgelser med de samme EF-holdnings-spørgsmål.

Et af de mere følelsesladede spørgsmål i kampagnen forud for folkeafstemningen var, hvad et medlemskab eventuelt kunne komme til at betyde for dansk national egenart og for mulighederne for at bevare en sådan egenart $i$ fremtiden. Blandt de mange emner, der $i$ øvrigt diskuteredes forud for afstemningen - måske dog mere i Sønderjylland end andre steder - var også grænselandsbefolkningens muligheder for at komme til at spille en rolle som en slags »brobyggere* i fremtidens Europa.

Det var for at undersøge, om sådanne spørgsmål havde været af særlig betydning i grupper af vælgere med forskelligt nationalt tilhørsforhold, at det blev besluttet at medtage et antal tidligere svarpersoner fra undersøgelsen i Nordslesvig i 2. interviewomgang af EFundersøgelsen. Hertil kom selvfølgelig, at det herved ville blive muligt også mere generelt at undersøge eventuelle forskelle $i$ holdninger til Europa imellem sådanne grupper.

\section{Folkeafstemningsresultatet i Sønderjylland}

Ser man på folkeafstemningsresultatet for landet som helhed, er to forhold væsentlige at hæfte sig ved. For det første var valgdeltagelsen 
den højeste, man endnu havde oplevet $\mathrm{i}$ landets politiske historie (90.4 pct.), og for det andet var ja-flertallet overordentlig klart (63.4 pct. ja-stemmer over for 36.6 pct. nej-stemmer). ${ }^{9}$

Hertil kommer, at selv en simpel undersøgelse af stemmetallene på amts- eller kommuneniveau ${ }^{10}$ afslører interessante træk i afstemningsmønstret. Således konstaterer man, at jo mindre graden af bymæssig bebyggelse er, jo større er andelen af ja-stemmer. Det viser sig også, at en geografisk faktor var af betydning, idet den storre andel af nejstemmer $\mathrm{i}$ landets østlige dele (specielt $\mathrm{i}$ det storkøbenhavnske område) gradvist ændres til meget klare ja-flertal, når man bevæger sig fra øst til vest. Dette er også tilfældet, når man tager hensyn til forskelle $\mathrm{i}$ bymæssighed og i tilslutning til de politiske partier.

Denne glidende overgang i EF-tilslutning kan betragtes under en centrum-periferi-synsvinkel, idet landets økonomiske og politiske centrum dels er at finde langt mod ost, dels havde de højeste nej-procenter. Heroverfor står så de 3 amter (Ringkøbing, Viborg og Sønderjylland), hvor der var de største ja-flertal (ca. 75 pct. ja mod 25 pct. nej). Som det ses, er det områder, der ligger omtrent så langt borte fra det politiske og økonomiske centrum, som det nu engang er muligt at komme i Danmark. Kun Nordjylland er i denne forbindelse afvigende, idet ja-flertallet kun var lidt større end landsgennemsnittet. Det bør erindres, at de nævnte 3 amter med de største japrocenter også er karakteriseret ved ikke at have meget store bysamfund og ved, at landbrug traditionelt har været et dominerende erhverv.

$\mathrm{Da}$ et af formålene med denne afhandling som ovenfor nævnt er at undersøge, om tilhørsforhold til det tyske mindretal er positivt forbundet med holdninger til EF, til dansk medlemskab i EF og til europxisk integration i det hele taget, er det et naturligt udgangspunkt at se på de officielle afstemningstal for Sønderjyllands Amt. I det tidligere nævnte arbejde ${ }^{11}$ om måling af nationalt tilhørsforhold er det blevet påvist, at isoleret betragtet er ingen af de undersøgte adfærdsformer velegnede til at drage præcise slutninger om mindretallets størrelse. For eksempel stemmer ikke alle, der identificerer sig med mindretallet, på Slesvigsk Parti ved folketings- og/eller kommunalvalg - selv om selvfølgelig de fleste gør det. Det betyder dog ikke, at man ikke kan bruge forskelle i Slesvigsk Partis stemmeandel i de forskellige kommuner som et fuldt anvendeligt udtryk for forskelle 
mellem kommunerne med hensyn til mindretallets relative størrelse, og Slesvigsk Partis stemmetal kan derfor udmærket bruges i denne type undersøgelser.

I tabel 1 er vist, hvorledes ja-procenten varierer mellem forskellige typer af kommuner i Senderjylland. Den inddeling af de 23 kommuner, der er foretaget her, bygger på: (1) Slesvigsk Partis styrke ved folketingsvalget $\mathrm{i} 1971,^{12}$ (2) procent $\mathrm{i}$ landbrug $\mathrm{m}$. v. af de erhvervsmæssigt besk ffigede ved folketællingen i 1970, og (3) stemmeprocenten ved folkeafstemningen i 1972.

Tabel 1. EF-afstemning, Slesvigsk Partis styrke og landbrugsprocenten. Ja-procent ved folkeafstemningen i 1972 i Sønderjylland efter Slesvigsk Partis styrke 1971, landbrugsprocent i $1970 \mathrm{og}$ stemmeprocent ved folkeafstemningen i de 23 kommuner.

\begin{tabular}{|c|c|c|c|c|c|}
\hline & & \multicolumn{4}{|c|}{ Slesvigsk Partis styrke 1971} \\
\hline & & \multicolumn{2}{|c|}{ Mindre end 3.5 pet. } & \multicolumn{2}{|c|}{3.5 pct. eller mere } \\
\hline & & \multicolumn{2}{|c|}{ Pct. i landbrug 1970} & \multicolumn{2}{|c|}{ Pct. i landbrug 1970} \\
\hline & & $\begin{array}{l}\text { Mindre end } \\
25 \text { pet. }\end{array}$ & $\begin{array}{l}25 \text { pct. } \\
\text { eller mere }\end{array}$ & $\begin{array}{l}\text { Mindre end } \\
25 \text { pct. }\end{array}$ & $\begin{array}{l}25 \text { pct. } \\
\text { eller mere }\end{array}$ \\
\hline \multirow{2}{*}{$\begin{array}{l}\text { Stemmepct. } \\
\text { ved } \\
\text { folke- } \\
\text { afstem- } \\
\text { ningen }\end{array}$} & $\begin{array}{l}\text { Mindre end } \\
91 \text { pet. }\end{array}$ & $\begin{array}{c}70.1 \\
(4)\end{array}$ & $\begin{array}{c}75.8 \\
(3)\end{array}$ & $\begin{array}{c}73.6 \\
(3)\end{array}$ & $\begin{array}{c}82.0 \\
(3)\end{array}$ \\
\hline & $\begin{array}{l}91 \text { pct. } \\
\text { eller mere }\end{array}$ & $\begin{array}{c}72.2 \\
(3)\end{array}$ & $\begin{array}{c}80.3 \\
(4)\end{array}$ & $\begin{array}{c}74.8 \\
(1)\end{array}$ & $\begin{array}{c}82.8 \\
(2)\end{array}$ \\
\hline
\end{tabular}

Note: Antal kommuner $i$ brer gruppe er angivet i parentes.

Kilder: Folkeafstemningen den 2. oktober 1972 om Danmarks tiltrxdelse af De curopaiske Fællesskaber,, Statistiske Efterretninger, 64. Argang, Nr. 71 (17. november 1972), tabel 8; Folketingsvalget den 21. september 1971 same folkeafstemningene, Statistiske Meddelelser, 1972:6, Kobenhavn, 1972, tabel I; og *Folke- og boligtxllingen 9. november 1970*, Statistisk Tabelverk, 1973:VI, Kabenhavn, 1973, tabel 2.

Det fremgår klart af tabel 1, at der for disse samlede, aggregerede, tal for kommunerne er en positiv sammenhæng mellem ja-procentens størrelse på den ene side og mindretallets styrke (som udtrykt ved Slesvigsk Partis styrke i 1971), de i landbrug m. v. beskæf tigedes andel af alle erhvervsmæssigt beskæftigede og stemmeprocenten på den anden side. Og disse sammenhænge forsvinder ikke, dersom man holder de 2 andre konstante.

Den positive sammenhæng mellem ja-procent og såvel landbrugs- 
procent som stemmeprocent er et trxk ved folkeafstemningen, der genfindes over hele landet. Det samme er tilfældet med det forhold, at landbrugsprocentens indflydelse på ja-procenten tydeligt nok er væsentligt større end stemmeprocentens.

Tabel 1 er som sagt ganske klar med hensyn til sammenhængen mellem mindretallets og ja-procentens størrelse. Uanset valgdeltagelsen og uanset hvor mange, der i 1970 var beskæf tiget ved landbrug $\mathrm{i}$ de forskellige grupper af kommuner, var der mindst 2.5 pct. flere ja-stemmer $\mathrm{i}$ de kommuner, der havde haft mindst 3.5 pct. stemmer på Slesvigsk Parti i 1971, end i de øvrige grupper af kommuner. I afsnittene 3 og 4 vil det blive vist, at denne sammenhæng, der kan konstateres for kommunerne, har sin klare parallel, når man skifter til det individuelle niveau, til de enkelte vælgere.

For en ordens skyld bør det måske nævnes, at de 3 kommuner i tabel 1, der dels havde en stemmeprocent på mindst 91, dels havde mere end 3.5 pct. tilslutning til Slesvigsk Parti i 1971, havde en tilslutning til mindretallets politiske parti, der var langt større, end tabellens inddeling lader ane. I virkeligheden havde Slesvigsk Parti i de 3 kommuner tilslutning fra mere end 10 pct. af alle stemmeberettigede i $1971 . .^{13}$

\section{Holdninger til EF $i 1971$}

Ved undersegelsen i Nordslesvig i efteråret 1971 blev der stillet adskillige spørgsmål, der vedrørte folks holdninger til De europxiske Fællesskaber. I dette afsnit vil svarene på disse spørgsmål blive sat $\mathrm{i}$ forhold til de adspurgtes subjektive nationale identifikation, altså de pågxldendes eget udsagn om, hvilken af de to nationalitetsgrupper de eventuelt følte, at de tilhørte. Grundlaget for tabellerne vil være begge de 2 interviews, der blev opnået med 637 personer i stikprøve 1 , der som ovenfor nævnt var udvalgt i Tønder og de kommuner, hvor der efter stemmetallene at dømme var flest mindretalsmedlemmer. ${ }^{14}$

Holdningen til EF blev målt ${ }^{15}$ ved hjælp af svar på nogle påstande om forhold $\mathrm{i}$ forbindelse med EF. ${ }^{16}$ Der var tale om i alt 7 påstande, og hvis de forskellige svar tillægges talværdier (fra 1 til 5, stigende jo mere positivt over for EF svaret er), kan man ved at addere disse talværdier få et udtryk, der - alle mangler til trods - kan bruges som et 
samlet udtryk for holdningen til EF. På denne såkaldte Fællesmarkedsskala har de mest positive over for EF de højeste skalaværdier. ${ }^{17}$ Skalaværdierne vil selvfølgelig variere mellem 7 og 35 .

I tabel 2 nedenfor er svarpersonerne blevet delt i 3 grupper efter skalaværdien på Fællesmarkedsskalaen, idet der er blevet medregnet tilnærmelsesvis lige mange skalaværdier til hver af de 3 grupper. Fordelen ved at samle materialet $i$ et beskedent antal grupper er dels, at det bliver mere overskueligt, dels at mere tilfældige småvariationer elimineres. Det fremgår af tabel 2, at der et år før folkeafstemningen var 18 pct. i dette særlige område, der blev placeret i den nederste tredjedel af skalaværdier, altså i den gruppe, der $\mathrm{i}$ tabellen har fået betegnelsen "lav«. De pågældende har altså for de 7 involverede påstande svarværdier, hvis gennemsnit er mindre end 2.28 (16:7). Det er nok forhastet uden videre at betegne denne gruppe som »fællesmarkedsmodstandere «, men under alle omstændigheder kan svarpersonerne i denne gruppe betegnes som noget beherskede i deres holdning til EF.

I den anden ende af skalaen finder vi betydeligt flere, idet 31 pct. havde yderst positive holdninger (gennemsnit på mindst 3.71); tilbage i midtergruppen bliver hele 51 pct.

Tabel 2. Holdning til EF i grupper med forsleelligt nationa't tilhorsforbold (august/september 1971). ${ }^{1}$ Procent.

\begin{tabular}{|l|c|c|c|c|c|c|}
\hline & $\begin{array}{c}\text { Stxrkt } \\
\text { dansk }\end{array}$ & $\begin{array}{c}\text { Mindre } \\
\text { stzrkt } \\
\text { dansk }\end{array}$ & $\begin{array}{c}\text { Hverken } \\
\text { dansk } \\
\text { el. tysk }\end{array}$ & $\begin{array}{c}\text { Mindre } \\
\text { stzerkt } \\
\text { tysk }\end{array}$ & $\begin{array}{c}\text { Stzrkt } \\
\text { tysk }\end{array}$ & Alle \\
\hline $\begin{array}{l}\text { Skalaverdit pd } \\
\text { EF-skalaen: }\end{array}$ & 26 & 10 & 5 & 5 & 2 & 18 \\
Lav & 50 & 59 & 59 & 48 & 42 & 51 \\
Middel & 24 & 31 & 36 & 47 & 56 & 31 \\
Hej & 100 & 100 & 100 & 100 & 100 & 100 \\
\hline I alt & 364 & 121 & 22 & 40 & 64 & $611^{5}$ \\
N = & & & & & & \\
\hline
\end{tabular}

1. Kun stikpreve 1 .

2. $* 2 v *=7-16, \rightarrow$ Middel $\alpha=17-25$ og $*$ Høj $<=26-35$.

3. 26 svarpersoner, der identificerede sig med andre nationaliteter, eller som svarede *Ved ikke*, er udeladt her.

Tabel 2 viser herudover det resultat, der fremkommer, hvis man sammenstiller interviewpersonernes holdning til EF - som udtrykt 
ved placering på denne nu tredelte skala - med deres subjektive nationale identifikation og styrken heri. Det billede, der viser sig herved, er kanske klart: Hvis man bevæger sig fra den store gruppe, der føler sig stærkt knyttet til det danske flertal, over grupperne i midten til gruppen, der føler sig stærkt knyttet til det tyske mindretal, ser man, at der samtidig sker en bevægelse $i$ retning af en langt mere positiv indstilling til EF og til dansk medlemskab deri. 56 pct. af de stærkt tyske var klart positive over for $\mathrm{EF}$, mens det kun var tilfældet med ca. en fjerdedel af de stærkt danske. Og omvendt var der blandt de stærkt danske godt en fjerdedel, der var ret så beherskede over for EF, medens det kun var tilfældet med 2 pct. af de stærkt tyske. Imellem disse 2 nationale yderpunkter ligger de tre grupper $\mathrm{i}$ midten, idet de også $\mathrm{i}$ henseende til EF-holdninger udgør midtergrupper.

Under valgkampen i 1971 blev det kraftigt understreget af de partier, der gik ind for dansk medlemskab af $\mathrm{EF}$, at folketingsvalget ikke havde noget med Fællesmarkedsspørgsmålet at gøre. Fællesmarkedsspørgsmålet blev dog alligevel et af valgkampens emner; for at undersøge, om der under valgkampen fandt en udvikling sted i vælgernes indstilling til EF, gentog vi i 2. runde i 1971-undersøgelsen en af de 7 påstande fra Fællesmarkedsskalaen. Den pågxldende påstand lød: „Vi skal under ingen omstændigheder melde os ind i Fællesmarkedet «. Vore hidtidige analyser havde vist, at af de enkelte påstande var det denne, der bedst satte os i stand til at sondre mellem tilhængere og modstandere i Fxllesmarkedsspørgsmålet. ${ }^{18}$

I tabel 3 er vist udviklingen for de personer, der havde et stærkt dansk tilhørsforhold. Det ses, at før valget var 31 pct. helt eller delvist enige i påstanden, medens 47 pct. helt eller delvist var uenige i den og derfor nærmest kan karakteriseres som tilhængere. Fordelingen på de 3 grupper ændredes faktisk ikke under valgkampen; ser man imidlertid på bevægelserne inde $i$ tabellen, bliver det klart, at kun ca. 2/3 af valgerne var stabile $i$ deres EF-holdninger, hvorved forstås, at de mente det samme efter som før valgkampen. Af de resterende var præcis halvdelen blevet mere positive, halvdelen mere negative, end de havde været før. Ser man nu på de personer, der identificerede sig stærkt med det tyske mindretal, viser det sig (tabel 4), at stabiliteten i denne holdning er større end tilfxldet var for de stærkt danske. 3/4, hvoraf næsten alle var positive over for Fælles- 


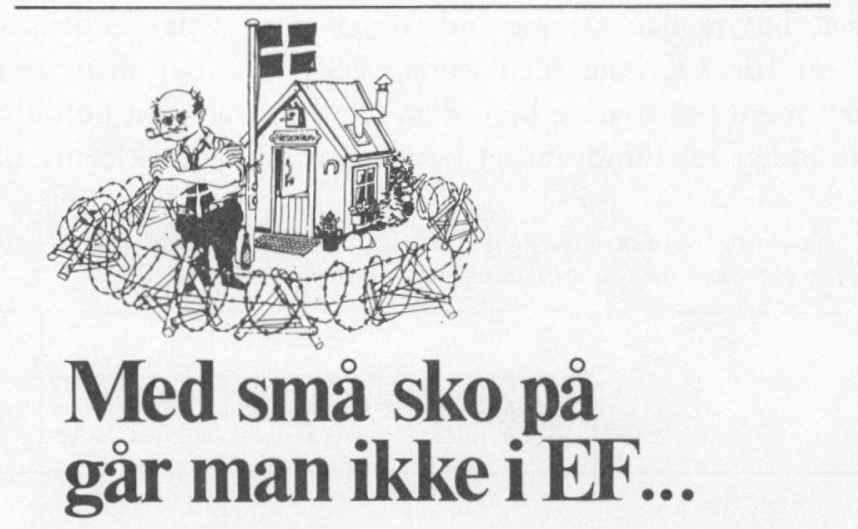

Det kan føles trist og en smule uværdigt, at så megen anti-EF-argumentation føres på småtskårent plan. Der appelleres med liv og lyst til primitiv nationalfølelse ("dansk forsvinder, ungerne skal tale tysk i skolen"), til den altid latente fremmed-modvilje ("prøjserne køber sku' hele Jylland"), til den velbjergedes angst for at skulle dele ("vi skal forsørge alle de spaghettifyre").

Ikke sandt? De argumenter har De hørt igen og igen - og ofte fra munde, der ellers er fulde af internationalisme, mellemfolkelig forståelse og øget u-landshjælp.

Mange af disse påstande fremsættes vist desværre mod bedre viden. For at få Dem til at sige NEJ. Men så små er Deres sko da ikke, vel?

\section{Komiteen for tilslutning til EF}

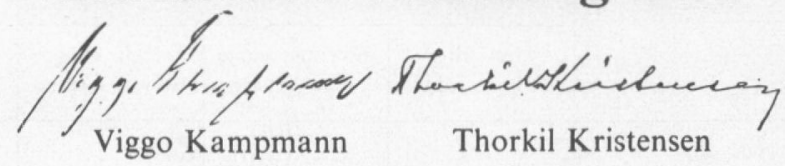

(lokalkomiteens navn.)

(komitemedlemmers navne.)

Ud over plakater var dagbladsannoncer en meget benyttet propagandaform $i$ EF-kampagnen. Her gengives en af tilhangernes mange annoncer, beregnet til supplering med lokale navne. 
markedet, havde den samme indstilling efter valgkampen, som de havde haft før. Og langt den største del af de, der skiftede indstilling, blev mere positive og kom derved til at dele den holdning, som de fleste inden for mindretallet havde. En mulig forklaring på dette

Tabel 3. Holdning til dansk medlemskab af $E F^{1}$ for og efter valget $i$ september 1971 blandt personer med starkt dansk tilhorsforbold.2 Procent.

\begin{tabular}{|c|c|c|c|c|c|}
\hline & \multicolumn{3}{|c|}{ Efter valget } & \\
\cline { 2 - 6 } & $\begin{array}{c}\text { Helt eller } \\
\text { delvist enige }\end{array}$ & $\begin{array}{c}\text { Hverken enige } \\
\text { eller uenige }\end{array}$ & $\begin{array}{c}\text { Helt eller } \\
\text { delvist uenige }\end{array}$ & 1 alt \\
\hline $\begin{array}{l}\text { Far } \\
\text { valget }\end{array}$ & $\begin{array}{l}\text { Helt eller } \\
\text { delvist enige } \\
\begin{array}{l}\text { Hverken enige } \\
\text { eller venige } \\
\text { Helt eller } \\
\text { delvist uenige }\end{array}\end{array}$ & 20 & 4 & 7 & 31 \\
\hline & 5 & 13 & 5 & 22 \\
\hline alt & 29 & 24 & 47 & $\begin{array}{c}100 \\
\mathrm{~N}=349\end{array}$ \\
\hline
\end{tabular}

1. Pł grundlag af svar på påstanden $-V i$ skal under ingen omstandigheder melde os ind i Frellesmarkedet*.

2. I stikprove 1.

3. Ved ikkee-svar er udeladt.

Tabel 4. Holdning til dansk medlemskab af $E F^{1}$ for og efter valget $i$ september 1971 blandt personer med sterkt tysk tilhersforhold.2 Procent.

\begin{tabular}{|l|l|c|c|c|c|}
\hline & \multicolumn{3}{|c|}{ Efrer valget } & \\
\cline { 2 - 6 } & $\begin{array}{c}\text { Helt eller } \\
\text { delvist enige }\end{array}$ & $\begin{array}{c}\text { Hverken enige } \\
\text { eller venige }\end{array}$ & $\begin{array}{c}\text { Helt eller } \\
\text { delvist venige }\end{array}$ & I alt \\
\hline $\begin{array}{l}\text { For } \\
\text { valget }\end{array}$ & $\begin{array}{l}\text { Helt eller } \\
\text { delvist enige } \\
\text { Hverken enige } \\
\text { eller uenige } \\
\text { Helt eller } \\
\text { delvist uenige }\end{array}$ & - & 2 & 11 & 15 \\
\hline & 2 & 3 & 5 & 11 \\
\hline I alt & 4 & 11 & 85 & 74 \\
\hline
\end{tabular}

1. På grundlag af samme påstand som i tabel 3.

2. Stikprove 1.

3. Ved ikkes-svar er udeladt. 
forhold kunne være den iver, hvormed Slesvigsk Parti $\mathrm{i}$ valgkampen understregede sin pro-europxiske indstilling. Det er vel overordentlig sandsynligt, at det har været med til at påvirke indstillingen hos de mindretalsmedlemmer, der før valget enten var modstandere af $\mathrm{EF}$ eller $\mathrm{i}$ tvivl om, hvad de skulle mene. Formodningen om, at en sådan påvirkning har kunnet finde sted, bygger blandt andet på, at mindretallets medlemmer i stort omfang også identificerer sig med Slesvigsk Parti.

De forskelle, der således kan konstateres mellem stærkt danske og stærkt tyske i denne stikprøve, kan ikke forklares ved henvisning til forskellene mellem de 2 grupper $i$ interesse i spørgsmålet eller ved forskelle $i$ det følelsesmæssige engagement i spørgsmålet, holdningens intensitet, som man også kalder det. Sådanne forskelle kan naturligvis konstateres. I tabel 5 er for eksempel vist de forskelle mellem de 5 grupper af nationalt tilhørsforhold, der ses med hensyn til det følelsesmæssige engagement $i$ spørgsmålet

Tabel S. Folelsesmessigt engagement i EF-sporgsmålet ${ }^{1}$ i grupper med forskelligt nationalt tilhørsforbold, 1971.2 Procent.

\begin{tabular}{|l|c|c|c|c|c|}
\hline & $\begin{array}{c}\text { Starkt } \\
\text { dansk }\end{array}$ & $\begin{array}{c}\text { Mindre } \\
\text { starkt } \\
\text { dansk }\end{array}$ & $\begin{array}{c}\text { Hverken } \\
\text { dansk } \\
\text { el. tysk }\end{array}$ & $\begin{array}{c}\text { Mindre } \\
\text { starkt } \\
\text { tysk }\end{array}$ & $\begin{array}{c}\text { Stzrkt } \\
\text { sysk }\end{array}$ \\
\hline Folelsesmassigt engageret: & & & & & \\
Meget & 14 & 12 & 9 & 22 & 30 \\
Noget & 32 & 27 & 27 & 33 & 34 \\
Kun lidt & 29 & 32 & 23 & 20 & 23 \\
Overhovedet ikke & 21 & 21 & 32 & 20 & 9 \\
Ved ikke og uoplyst & 4 & 8 & 9 & 5 & 3 \\
\hline I alt & 100 & 100 & 100 & 100 & 100 \\
N = & 364 & 121 & 22 & 40 & 64 \\
\hline
\end{tabular}

1. Spørgsmålet lød: Nogle mennesker er meget folelsesmassigt engageret i sporgsmålet om Danmarks indtreden i Fallesmarkedet, medens andre ikke er det. Vil De sige, at De er meget, noget, kun lidt eller overhovedet ikke følelsesmessigt engageret i spargsmålet?e

2. Stikprove 1.

Af tabel 5 fremgår, at det følelsesmæssige engagement $i$ spørgsmålet er en anelse mindre blandt de mindre stærkt danske end blandt de, hvis identifikation med flertallet er stærk. Gruppen, der betegner sig selv som hverken dansk eller tysk, er den mindst engagerede, medens begge de tyske grupper har et stærkere engagement i sagen 
end nogen af de 2 danske grupper. Sammenligner man derefter de 2 grupper, der $\mathrm{i}$ forskellig grad føler sig tilknyttet mindretallet, er der en markant forskel, idet de, der identificerer sig stærkt med mindretallet, også har det stærkeste engagement i EF-spørgsmålet.

Hvis man derefter sammenstiller stabiliteten i EF-holdninger med enten interesse eller følelsesmæssigt engagement $i$ spørgsmålet, og herunder tager hensyn til forskelle i nationalt tilhørsforhold, bliver resultatet et noget forvirrende billede. Dette forer til den konklusion, at de forskelle, der kunne konstateres mellem tabellerne 3 og 4, tilsyneladende ikke kan forklares ved forskellene $\mathrm{i}$ interesse eller følelsesmæssigt engagement.

Hvis vi forlader spørgsmålet om holdningens stabilitet under valgkampen, og i stedet ser på dens retning (her: positiv eller negativ over for $\mathrm{EF}$ ), er det rimeligt kun at se på de personer, der identificerer sig med det danske flertal, idet vi ovenfor har set, at næsten alle mindretallets medlemmer havde en positiv holdning til EF. Tabel 6 nedenfor omfatter derfor kun personer, der enten foler sig stærkt knyttet til det danske flertal eller mindre stærkt knyttet til den samme gruppe. For begge kategorier viser det sig, at personer, der havde en positiv holdning, var noget mere engagerede i spørgsmålet, end de, der var mere negative over for Fællesmarkedet og Danmarks medlemskab.

Tabel 6. Folelsesmossigt engagement $i$ EF-spørgsmalet ${ }^{1}$ efter boldningens retning ${ }^{2}$ og efter styrke $i$ det danske nationale tilborsforbo!d, 1971. ${ }^{3}$ Procent.

\begin{tabular}{|l|c|c|c|c|}
\hline & \multicolumn{2}{|c|}{ Stretkt dansk } & Mindre stxerkt dansk \\
\cline { 2 - 5 } & Negativ & Positiv & Negativ & Positiv \\
\hline Folelsesmessigt & & & & \\
engagement: & 14 & 19 & 10 & 15 \\
Meget & 27 & 39 & 20 & 30 \\
Noget & 33 & 24 & 30 & 38 \\
Kun lidt & 22 & 17 & 35 & 14 \\
Overhovedet ikke & 4 & 1 & 5 & 3 \\
Ved ikke og uoplyst & 100 & 100 & 100 & 100 \\
\hline I alt & 102 & 165 & 20 & 66 \\
N = & & & & \\
\hline
\end{tabular}

1. Samme sporgsmal som i tabel 5 .

2. Kun svarpersoner, som har oplyst en negativ eller en positiv retning på deres holdning til EF.

3. Kun stikprøve 1 . 
Ser man dernæst på, om der eventuelt skulle være tilsvarende forskelle i de to kategoriers interesse $\mathrm{i}$ sagen, så viser der sig endnu klarere forskelle mellem negative og positive, mellem modstandere og tilhængere. Omkring halvdelen af tilhængerne i de to kategorier siger, at de er meget interesserede, medens det kun er tilfældet med ca. 1/3 af modstanderne. ${ }^{19}$

Hvis man vil forsøge at forklare ja-tilhængernes store succes $\mathrm{i}$ kampagnen forud for folkeafstemningen i oktober 1972, er det mere beskedne følelsesmæssige engagement og den mindre interesse hos modstanderne sandsynligvis en meget betydningsfuld faktor. Om denne formodning vil vise sig holdbar også på landsplan må udskydes til senere analyser af vort materiale.

\section{EF-boldninger $i 1972$ i grupper med forskelligt nationalt tilhørsforbold}

For ikke at komplicere udvælgelsesproceduren yderligere udvalgtes fra den nordslesvigske undersøgelse i 1971 de personer, der også skulle med i EF-undersøgelsen året efter, alle blandt interviewpersonerne fra den oprindelige stikprøve 1. De 637 personer, som vi havde 2 interviews med fra 1971, blev af hensyn til udvælgelsen af personer til denne 3. omgang delt i 4 grupper på grundlag af følgende $3 \mathrm{kri}-$ terier:

1. Den subjektive nationale identifikations retning (dansk eller tysk).

2. Den subjektive nationale identifikations styrke (stærk eller mindre stærk).

3. Skalaværdi i forbindelse med den adfærdsmæssige nationale identifikation. Skalaværdien varierer mellem 0 og 8 , idet skalaen er konstrueret ud fra 8 nationalt relevante former for adfærd (at stemme på Slesvigsk Parti ved forskellige lejligheder, tale tysk hjemme, læse Der Nordschleswiger etc.) ${ }^{20}$

De 4 grupper, der opstilledes herudfra, kan beskrives på følgende måde:

1. Svarpersoner, der følte sig stærkt knyttet til det danske flertal, og som ikke udviste nogen form for »tysk « adfærd. 
2. Svarpersoner, der hverken regnede sig som hørende til flertallet eller til mindretallet, og som udviste mindre end 6 af de omtalte 8 »tyske « adfærdsformer, eller svarpersoner, der følte sig "mindre stærkt « knyttet til det danske flertal, og som havde en skalaværdi på mindst 1 med hensyn til adfærdsmæssig identifikation.

3. Svarpersoner, der følte sig knyttet til det tyske mindretal - uanset styrken - og som havde mindst 2 af de omtalte »tyske« adfærdsformer.

4. Alle andre.

I 3. interviewomgang inkluderedes alle svarpersoner, der var blevet placeret $\mathrm{i}$ grupperne 2 og 3 , sammen med en tilfældig stikprøve af personerne $i$ den første gruppe. ${ }^{21}$ Det er de 3 interviews med disse personer, der er grundlaget for dette afsnit. Oprindeligt sigtede vi mod, at der skulle udvælges ca. 200 personer. Den foretagne gruppering førte til et udvalg på 215 personer. Af disse opnåedes det 3. interview med $i$ alt 187 personer, svarende til en svarprocent på 87.0, hvad der må betegnes som yderst tilfredsstillende.22 Men selv om svarprocenten således er høj, indgår der altså kun 187 personer i denne fase af undersøgelsen.

Stemmefordelingen ved folkeafstemningen $\mathrm{i}$ oktober 1972 inden for de tre grupper fremgår af tabel 7:

Tabel 7. Stemmeafgivning ved EF-folkeafstemningen $i 1972$ i 3 grupper med forskelligt nationalt tilbørsforbold. Procent.

\begin{tabular}{|l|c|c|c|}
\hline & Stærkt dansk & Midtergruppen & Tysk \\
\hline Stemte ja & 72 & 82 & 93 \\
Stemte nej & 25 & 7 & 1 \\
Stemte ikke (og \\
*vil ikke svare*)
\end{tabular}

Selv om svarpersonerne er udvalgt $\mathrm{i}$ områder, der blandt andet havde en stemmeprocent ved folkeafstemningen på mindst 91 , og som havde meget høje ja-flertal, så er såvel stemmedeltagelsen som ja- 
majoriteten i dette materiale overraskende høje. Imidlertid må man huske på, at de 187 personer i denne del af undersøgelsen har ladet sig interviewe 3 gange. Det er $\mathrm{i}$ sig selv en antydning af en politisk og/eller national interesse hos de pågxldende, som rimeligvis også må føre til en endnu højere valgdeltagelse, end den man ellers så blandt vælgerne.

Selv om en sammenligning ikke umiddelbart lader sig foretage, så er der dog alligevel betydelige lighedspunkter mellem tallene i tabel 7 og de tal, vi så i tabel 2 om holdninger til EF i 1971 i hele stikprøve 1. Også i 1972 finder man langt den mindste tilslutning til EF blandt de, der føler sig stærkt knyttet til det danske flertal - omend flertallet for tilslutning til EF dog også var meget klart i denne gruppe. Og ligeledes finder man så langt den kraftigste tilslutning blandt mindretalsmedlemmerne. Ved folkeafstemningen var der $\mathrm{i}$ denne gruppe - som det fremgår af tabel 7 - mere end 90 pct., der stemte ja til EF. Og også i 1972 placerer midtergruppen i national henseende ${ }^{23}$ sig imellem de andre grupper med hensyn til EF-tilslutning.

Men selv om disse fælles træk kan konstateres, så må man også ved en sammenligning af tabel 2 og tabel 7 bemærke, at selv om der blandt de stærkt danske var en meget betydelig del (50 pct.), der $\mathrm{i}$ 1971 blev placeret i gruppen med de midterste skalaværdier på EFskalaen, så var som tidligere understreget ja-flertallet i 1972 dog ganske klart også i denne gruppe. Tager man resultaterne af tabel $3 \mathrm{i}$ betragtning, bliver det også klart, at trods al usikkerhed mente ca. halvdelen af de stærkt danske i efteråret 1971, at vi skulle melde os ind i Frllesmarkedet. Hertil kommer, at en del af de usikre selvfølgelig også ville have stemt ja. Alligevel er de 72 pct. ja-stemmer i tabel 7 ganske højt, og det må derfor være rimeligt at se lidt nærmere på stabiliteten $\mathrm{i}$ holdningerne til EF og til Danmarks medlemskab heri.

I tabel 8 er for hver af de 3 grupper vist, hvorledes holdningerne til EF udviklede sig imellem 1. interviewomgang før folketingsvalget i september 1971 og 3 . interviewomgang efter folkeafstemningen i oktober 1972. Da vi primært er interesseret $\mathrm{i}$ holdningerne på tidspunktet for folkeafstemningen, må vi gøre den forudsætning, at der ikke er sket væsentlige holdningsskift $\mathrm{i}$ den meget korte periode mellem afstemningen og interviewet. 


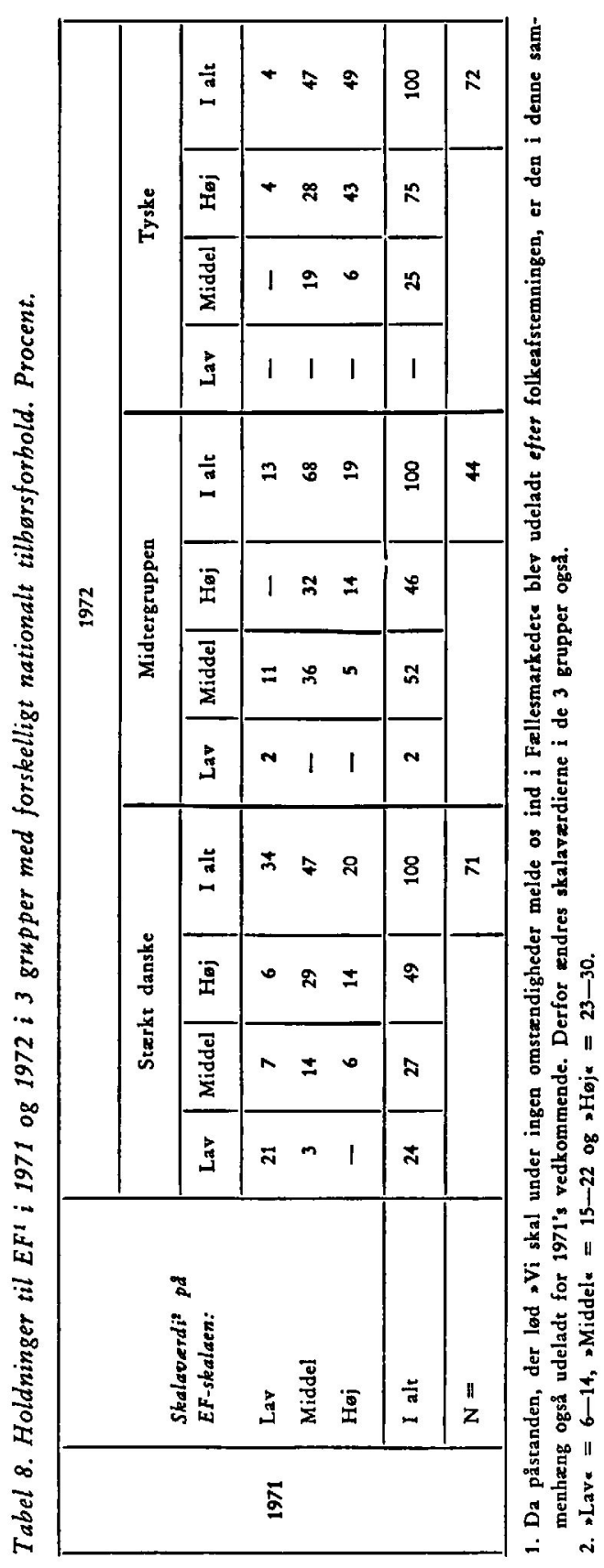




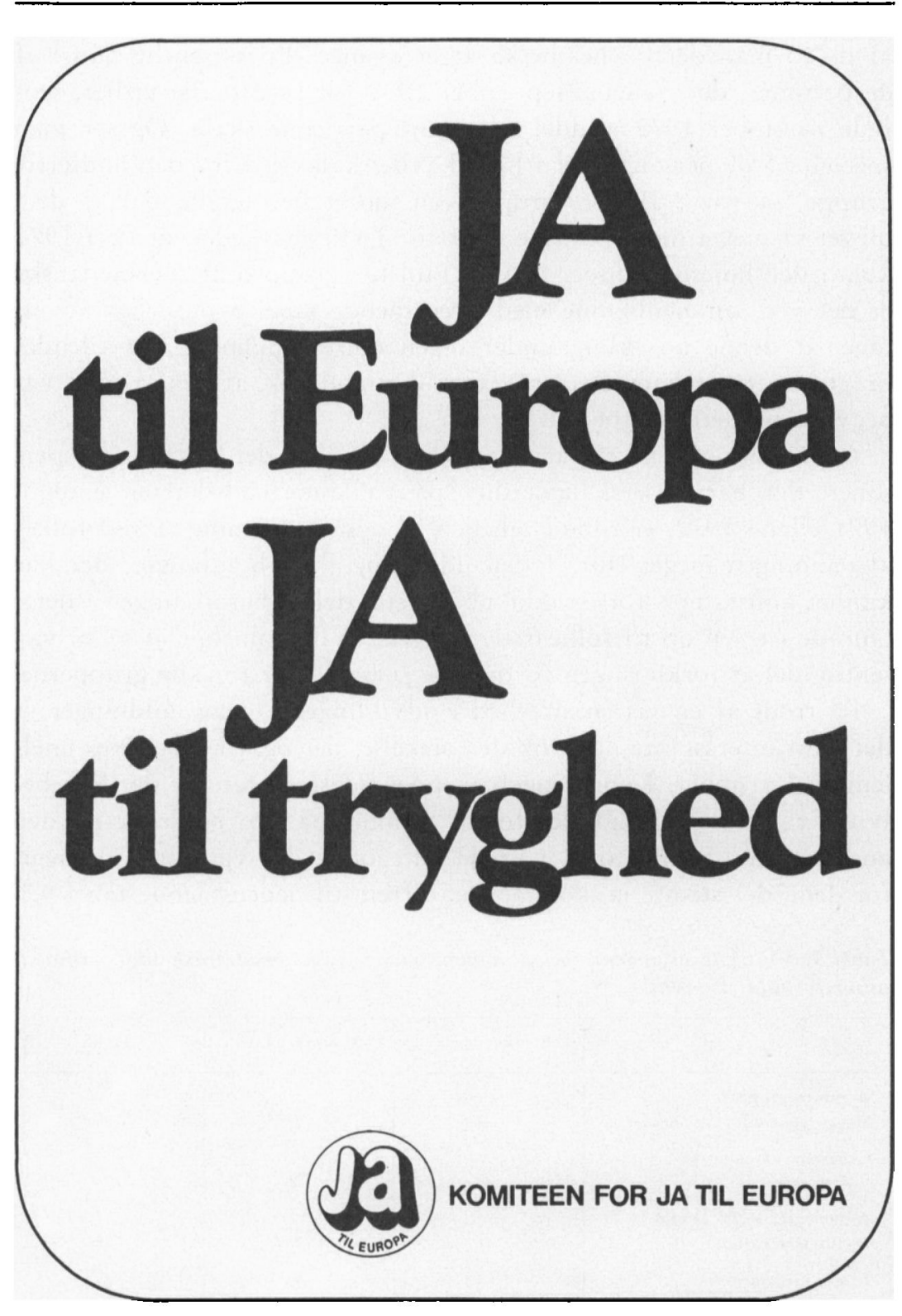

Det fremgår klart af tabel 8, at der i alle tre grupper har været en betydelig bevægelse $i$ retning af en mere positiv indstilling i lobet 
af de 13 måneder, vi her beskæftiger os med. En væsentlig andel af de personer, der $\mathrm{i}$ august/september 1971 fik lave skalaværdier, scorede $\mathrm{i}$ oktober 1972 middel eller højt på denne skala. Og ser man specielt på de personer, der i 1971 havde skalaværdier i den midterste gruppe, så var $i$ alle tre grupper en meget betragtelig del af dem blever så meget mere positive over for Fællesmarkedet, at de i 1972 kom $\mathrm{i}$ den højeste gruppe. I hvert fald for gruppen af stærkt danske er det ved sammenligning med ovenstående tabel 3 naturligt at antage, at denne udvikling under ingen omstxndigheder var tilendebragt under valgkampen 1971, men derimod nok, at den så småt var begyndt på dette tidspunkt.

Af tabeller, der ikke er medtaget her, fremgår det klart, at for personer, der har høje skalaværdier på Fællesmarkedsskalaen enten i 1971 eller i 1972, er tilbøjeligheden til også at stemme ja ved folkeafstemningen meget stor. I den udvikling i EF-holdninger, der har kunnet konstateres for en ikke ubetydelig del af befolkningen i dette område i tiden op til folkeafstemningen, er det rimeligt at se en vxsentlig del af forklaringen på de høje ja-procenter for alle grupperne.

$P a ̊$ trods af en vis ensartethed $i$ udviklingen $i$ disse holdninger er det mest interessante dog nok de forskelle, der også konstateres imellem de 3 grupper. I undersøgelsen indgår også materiale, der kan belyse vælgernes begrundelser for at stemme på den ene eller på den anden måde. Samler man $\mathrm{i}$ brede kategorier det vigtigste argument for dem, der stemte ja, kommer man frem til nedenstående tabel $9 .{ }^{24}$

Tabel 9. Vigtigste argument for at stemme ja $i$ grupper med forskelligt nationalt tilhørsforbold. Procent.

\begin{tabular}{|l|c|c|c|}
\hline & Stzrkt danske & Midtergruppen & Tyske \\
\hline $\begin{array}{l}\text { Argumentgrupper; } \\
\text { Meget generelle argumenter }\end{array}$ & 41 & 31 & 25 \\
$\begin{array}{l}\text { Generelle okonomiske } \\
\text { argumenter }\end{array}$ & 31 & 25 & 24 \\
Argumenter redr. enkelt- \\
gruppers forhold
\end{tabular}




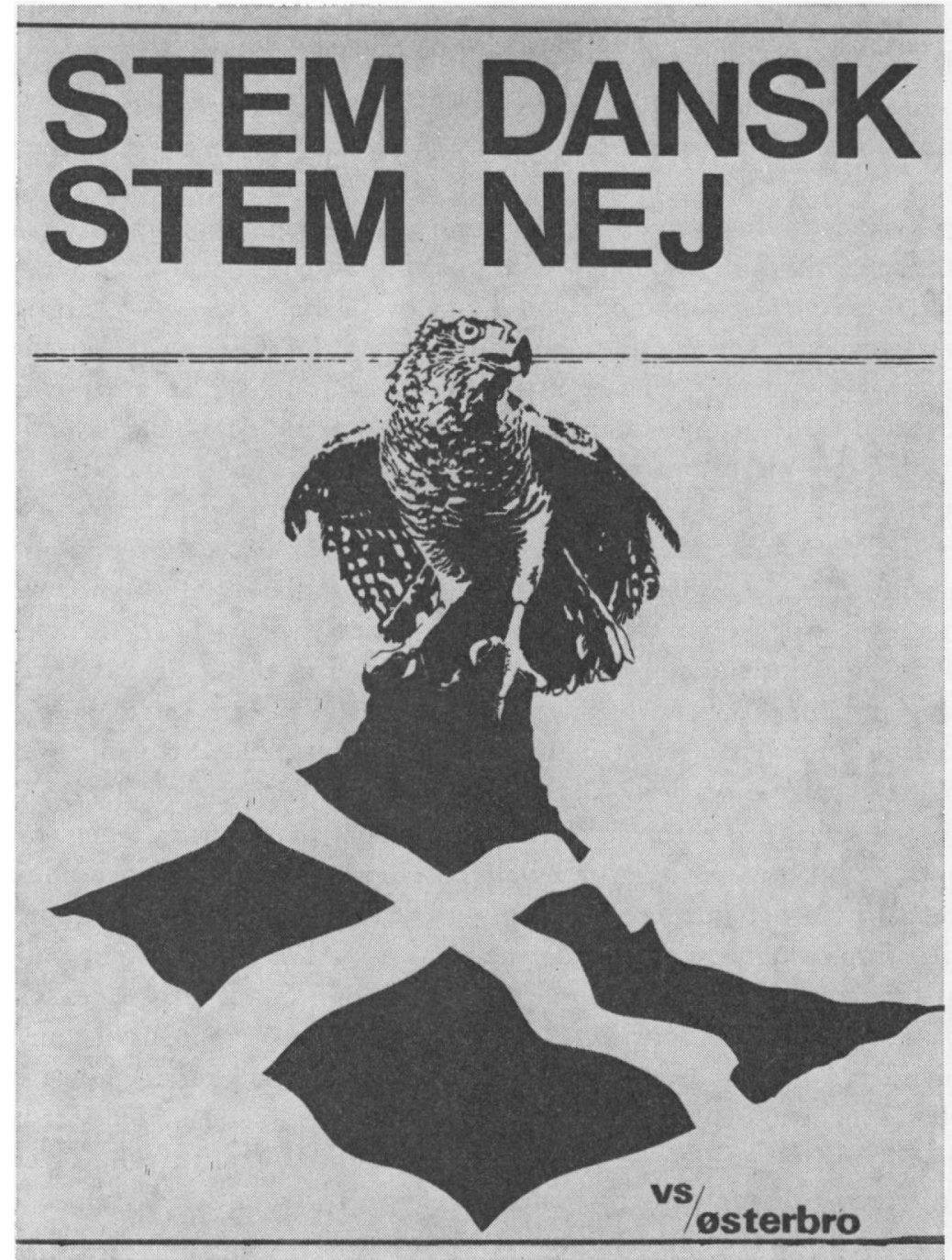

Karakteristisk nok fandt man de mest antityske indslag $i$ debatten uden for Nordslesvig. $\mathrm{Og}$ den mest nationalistiske tone var nok at finde pd venstrefløjen.

Igen ser man det efterhånden velkendte mønster med de stærkt danske og de tyske, der afviger en del fra hinanden, medens midtergruppen også $\mathrm{i}$ henseende til argumentation for at stemme ja placerer 
sig imellem de 2 andre grupper. Sxrligt slående er forskellen mellem de to ydergruppers argumentation. Mindretalsmedlemmerne fremlagde således ideelle argumenter $\mathrm{i}$ omtrent samme omfang som andre argumenter, medens det for de stærkt danske var en argumentkategori af meget ringe betydning. Til gengxld var der en meget stor gruppe af mere generelle argumenter, af nationaløkonomisk og almindelig udviklingsmæssig art. Man kan måske også hæfte sig ved, at der i den tyske gruppe også blev lagt betydelig vægt på enkeltgruppers forhold. Specielt blev betydningen for landbruget af EF-medlemskab fremhævet. Det er nok ikke uden sammenhæng med, at det er $\mathrm{i}$ den tyske gruppe, man finder forholdsvis flest landmænd.

Med den meget begrænsede modstand imod dansk indtræden i EF, som vi har kunnet konstatere blandt de adspurgte i denne stikprøve, er der også indirekte svaret på spørgsmål om betydningen af nejargumenter, der enten var anti-tyske $i$ deres indhold, eller som understregede et ønske om at bevare dansk national egenart (og mente, at det kun kunne ske uden for EF). Argumenter af disse typer optræder så godt som ikke $\mathrm{i}$ vort materiale. Hovedargumentet for Fællesmarkedsmodstanderne $\mathrm{i}$ vort materiale er det synspunkt, at medlemskab på væsentlige områder vil betyde en suverænitetsafgivelse.

Den mere pro-europxiske indstilling, som man finder $i$ det tyske mindretal, viser sig også, når man forlader spørgsmålet om holdninger til EF $\mathrm{i}$ dets nuværende form og mere generelt ser på holdninger til europxisk integration $i$ det hele taget. ${ }^{25}$ Sådanne holdninger har vi forsøgt at få et indtryk af ved at bede om de adspurgtes reaktion på 4 spørgsmål om indstilling til fælleseuropæisk regering, parlament, præsident og forbundsstat. Små skalaværdier udtrykker en modstand eller tilbageholdenhed over for sådanne tanker, medens høje værdier er udtryk for en betydelig grad af tilslutning. For at afrunde fremstillingen $i$ dette afsnit er $i$ tabel 10 vist, hvorledes de 3 grupper afviger med hensyn til holdning til europxisk integration $i$ det hele taget, idet skalaværdierne er blevet samlet i 3 grupper. Det bemærkes at tabel 10 kun omfatter personer, der stemte "ja* ved folkeafstemningen.

Også i tabel 10 finder man bekræftet den mere pro-europæiske indstilling i det tyske mindretal, idet over halvdelen scorer højt på denne skala. Den betydelige reservation over for en videregående europxisk integration, som tabellen tyder på er til stede såvel blandt de stærkt 
Tabel 10. Holdning til europaisk integration $i$ det bele taget blandt de, der stemte $j a, i$ de 3 grupper med forskelligt nationalt tilhørsforbold. Procent.

\begin{tabular}{|l|c|c|c|}
\hline & Starkt danske & Midtergruppen & Tyske \\
\hline $\begin{array}{l}\text { Skalavardi pd skala vedr. } \\
\text { europaisk integration: } \\
\text { Lav }\end{array}$ & 18 & & \\
Middel & 53 & 28 & 12 \\
Høj & 29 & 39 & 31 \\
\hline I alt & 100 & 33 & 57 \\
N $=$ & 51 & 100 & 100 \\
\hline
\end{tabular}

danske som i midtergruppen, er $\mathrm{i}$ øvrigt ikke et fænomen, der på nogen måde er specielt for det område, hvor denne stikprøve er udvalgt. ${ }^{26}$ Ejheller er det et fænomen, der kun kunne konstateres i 1972, i forbindelse med folkeafstemningen. En undersegelse i 1973 gav således samme resultat. ${ }^{27}$

\section{Afslutning}

På grundlag af et interviewmateriale fra de egne af Nordslesvig, hvor man ud fra stemmetallene må antage, at der bor forholdsvis flest medlemmer af det tyske mindretal, er holdninger til EF og til europxisk integration $\mathrm{i}$ øvrigt blevet sat $\mathrm{i}$ relation til de adspurgtes nationale tilhørsforhold, således som de selv havde givet udtryk for dette.

På alle de undersøgte områder peger resultaterne i samme retning: Medlemmerne af det tyske mindretal har mere udtalte pro-europxiske holdninger end det danske flertal, de er mere positive over for Fælles-markedet, de stemte ja $\mathrm{i}$ langt større omfang osv. De grupper, der $i$ henseende til nationalt tilhørsforhold placerer sig imellem de to ydergrupper, har tilsyneladende også EF- og Europa-holdninger, der ligger imellem de stærkt danskes og mindretalsmedlemmernes.

Også styrken $i$ det nationale tilhørsforhold spiller en væsentlig rolle. Således er stærkt tyske mere positive over for EF osv. end de mindretalsmedlemmer, hvis nationale identifikation er mindre stærk. Og på tilsvarende måde er de stærkt danske mere reserverede $\mathrm{i}$ deres holdninger til de undersøgte forhold end de mindre stærkt danske. 


\section{NOTER}

1. Denne artikel er en revideret udgave af et foreløbigt paper med titlen $\gg \mathrm{Na}$ tional Identification and Attitudes towards the EC«, som blev fremlagt på en såkaldt planning session under European Consortium for Political Research i Strasbourg i dagene 29. marts-2. april 1974.

2. Det drejer sig om Peter Hansen, Nikolaj Petersen og Ole Tonsgaard ved Institut for Statskundskab og om Johan Peter Noack ved Historisk Institut.

3. Undersøgelsen er under betegnelsen „Den Sønderjyske Vælgeradfærdsundersøgelse 1971 « blevet gennemfort med teknisk bistand fra Socialforskningsinstituttet og på grundlag af bevillingsmæssig støtte fra Statens samfundsvidenskabelige Forskningsråd, bevillingsnumrene 514-1026 og 514-1566.

4. For en kort oversigt over hele projektet, der også omfatter en liste over de indtil nu udsendte arbejdspapirer, kan der henvises til Jørgen Elklit, Johan Peter Noack og Ole Tonsgaard, $₫$ En politisk-sociologisk undersøgelse af det tyske mindretal i Nordslesvig. En oversigt «, Nordisk Minoritetsforskning, 1. årgang, Nr. 2 (1974), et nyt tidsskrift, som er under udgivelse. Blandt de udsendte arbejdspapirer kan fremhæves Jørgen Elklit, Johan Peter Noack og Ole Tonsgaard, „Om måling af nationalt tilhørsforhold i Nordslesvig«, Økonomi og Politik, Årgang 46, Nr. 4, 1972 (1973), pp. 375-395; Jørgen Elklit, »De sønderjyske valgere og spærrereglen «, Sønderjysk Manedsskrift, 49. årgang, Nr. 2 (1973), pp. 64-74; og Spørgeskemaer med marginaler, Århus: Institut for Statskundskab, Aarhus Universitet, september 1972 (stencil.). Dette sidste arbejdspapir kan sammen med øvrige duplikerede arbejder fra undersøgelsen rekvireres - så langt oplagene rækker - ved henvendelse til Institut for Statskundskab, Universitetsparken, 8000 Århus C.

5. Elklit, Noack og Tonsgaard, op. cit., 1973, p. 380.

6. Der er tale om en Guttman-skala, bestående af 8 items.

7. Det drejer sig om Burkal, Højer Flække, Højer Landsogn, Ravsted, Tinglev, Ubjerg og Uge.

8. Projektet gennemføres for midler fra Dansk Udenrigspolitisk Institut og fra Statens samfundsvidenskabelige Forskningsråd (bevillingsnummer 514-1512).

9. De angivne procenter er beregnet uden hensyntagen til det grønlandske afstemningsresultat.

10. Nikolaj Petersen and Jørgen Elklit, "Denmark Enters the European Communities «, Scandinavian Political Studies, Vol. 8 (1973), p. 209.

11. Elklit, Noack og Tonsgaard, op. cit., 1973.

12. Slesvigsk Partis procentuelle styrke er overalt $i$ denne afhandling beregnet på grundlag af samtlige stemmeberettigede. Folkeafstemningens ja-procent er derimod beregnet på grundlag af de afgivne stemmer.

13. De 3 kommuner er Højer, Tinglev og Tønder.

14. De pågældende områder ligger alle inden for grænserne af de 3 nye storkommuner, der er næunt i note 13.

15. Som en introduktion til holdningsmålinger kan der for eksempel henvises til Karl W. Redder, Karen Siune og Ole Tonsgaard, Introduktion til sociologisk metode, København: Munksgaard, 1970, Kapitel V.

16. Påstandenes ordlyd kan ses i Spørgeskemaer med marginaler, op. cit., pp. 3132.

17. DP-værdier for denne Likert-skala kan ses $i$ den første version af dette arbejde (se note 1), p. 47.

18. $\mathrm{DP}=3.0$. 
19. Af pladshensyn er den pågxldende tabel udeladt.

20. Se nærmere herom i Elklit, Noack og Tonsgaard, op. cit., 1973, pp. $380 \mathrm{ff}$.

21. Der udvalgtes maskinelt 25 pct.

22. Til den 1. gruppe (stærkt dansk) udvalgtes 81 , og 71 interviews opnåedes (87.7 pct.). I gruppe 2 (midtergruppen) indgik 58 personer, hvoraf 44 blev interviewet ( 79.9 pct.). Endelig var der $\mathrm{i}$ gruppe 3 (tysk) så mange som 72 af 76 , der blev interviewet ( 94.7 pct.).

23. Der erindres om, at denne midtergruppe er defineret anderledes $i$ tabel 7 end i tabel 2.

24. Billedet ændres ikke væsentligt, hvis man også inddrager begrundelse nr. 2 og 3, som vi også bad de adspurgte oplyse.

25. En mere generel redegørelse for disse holdningers placering i hele EF-undersøgelsen er givet i Nikolaj Petersens foreløbige paper til ECPR-konferencen i Strasbourg, „Europeanism in the Danish Foreign Policy Universe«. En stærkt revideret udgave heraf vil blive offentliggjort $\mathrm{i}$ tidsskriftet Cooperation and Conflict.

26. Se Nikolaj Petersen, op. cit., pp. 23 ff.

27. Se J.-R. Rabier, Sondage ,Communauté Européenne 1973*: L'Europe vue par les Européens, Bruxelles, Commission des Communautés Européennes, 28. 1. 1974 (stencil.), Tabel 2.

Illustrationerne er venligst stillet til rådighed af Nationalmuseet. 